\title{
When Words Matter: Language Choices and Brand Building on Two Global Coffee Shop Retail Brands in Indonesia
}

\author{
Jovid Jonathan Latukolan', Rustono Farady Marta ${ }^{2}$, Engliana ${ }^{3}$ \\ ${ }^{1,2,3}$ Faculty of Communication, Bunda Mulia University, Indonesia \\ jovidjonathan@gmail.com,rmarta@bundamulia.ac.id,engliana.seok@gmail.com
}

\begin{abstract}
English is an essential element in the field of marketing communication. The use of sound and correct language can provide its image for the public to view its brand's image. The use of foreign language itself is one form of forming a brand image so that the public or potential consumers themselves can see a brand with a more positive image. This study aims to look at the purpose of implementing language choice on the Instagram page of Starbucks Indonesia and Coffee Bean Indonesia in building the brand image of these two global coffee shop brands in Ramadan month and the Eid celebration. This study employs a qualitative approach with an interpretive research paradigm. Laura Oswald's marketing semiotics is the analytical method used in the current study. This study indicates that Starbucks Indonesia and Coffee Bean Indonesia have different target markets and distinctive brand images. Starbucks Indonesia uses simple words and sentences. Starbucks has a more personal or individual promotion; Coffee Bean Indonesia has a more dynamic approach and has word choices that are immediately related to religion and culture; the image created by Coffee Bean itself is familiar to the Indonesians and their social environment.
\end{abstract}

\section{Keywords}

language choice; brand image; brand building; marketing semiotics; Ramadhan; Eid

\section{Introduction}

Starbucks is a global brand that is already very global; it is recorded that until 2021 Starbucks coffee shops already exist in 61 countries with several outlets reaching 20,336 outlets worldwide. It proves that this coffee shop, first established in 1971 in the United States and is a coffee shop favored by the global community. Another global coffee brand from Uncle Sam's country, famous as Starbucks, is Coffee Bean. Coffee Bean itself already exists in 25 different countries with 1,200 outlets. Therefore, Starbucks and Coffee Bean can be regarded as global coffee companies with loyal fans and customers in their respective countries.

Indonesia is one of the countries where these two coffee outlets opened branches; it was recorded that in 2019 the Coffee Bean outlets in Indonesia had reached 101 outlets throughout Indonesia. Starbucks had 421 outlets spread across the city in the same year. In Indonesia, both Starbucks and Coffee Bean turn to social media platforms to run their advertising campaigns and building brand image. Instagram is one of the social media platforms chosen by Starbucks and Coffee Bean as media for promotion and branding of their outlets. The advertising campaign using Instagram accounts are successful in building their brands. from the successful campaigns are visible from the number of followers of the these two Instagram accounts, which amounts to $1,5 \mathrm{M}$ followers for the Starbucks Indonesia Instagram account and 36,1K followers for the Coffee Bean Indonesia Instagram account. 
Both of these two coffee shop brands share almost the same target market. Of course, these two global companies must have their way of attracting the attention of their potential customers. Moreover, the COVID-19 pandemic has caused a massive decline in sales as recorded that in the second quarter of 2020, there was an economic decline in Indonesia of 5.32\% compared to 2019 (BPS, 2020).

According to the Central Statistics Agency (BPS) data, the food and beverage industry companies that are most affected by the most significant impact are the food and beverages business. Starbucks Indonesia and Coffee Bean Indonesia are companies in the food and beverages sector, which experience a domino effect from the COVID-19 outbreak and Large-scale Social Restriction (PSBB), which has occurred in almost all major cities in Indonesia. In 2020, Starbucks alone experienced a decline in sales of up to $50 \%$ from the previous year (Diah, 2020). Starbucks Indonesia and Coffee Bean Indonesia have experienced a massive decline in sales due to the COVID-19 outbreak.

However, Starbucks Indonesia and Coffee Bean Indonesia start to get busy again by customers and their outlets are committed to carrying out health protocols set by the Indonesian government and the WHO. Of course, Starbucks and Coffee Bean outlets' reopening requires publicity or promotion. They turn to their Instagram accounts as a platform to promote the brand again. They made the right choice by turning to social media platforms to starting promotional campaigns. According to Google Consumer Behavior, $50 \%$ of Indonesians themselves already used the Internet in their daily lives (Harita et al., 2020). Nevertheless, one interesting thing about the two global coffee company accounts is English, which is almost always in their uploads on the Instagram of the two coffee brands.

For a product originating from abroad to be marketed or to market products abroad, a global communication tool or means of communication is required where the product comes (Rahayu, 2018). English is now a lingua franca (Crystal, 2003). Its superiority over languages other than English is statistically evident from the number of English speakers, which reaches 380 million users globally and ranks third as the language with the most speakers in the world (Cailey Johanna, 2021). Therefore, it is not surprising that Starbucks Indonesia and Coffee Bean Indonesia uses English in almost every Instagram upload. This study seeks an overview of how the English language is used - the word choices - on Starbucks Indonesia and Coffee Bean Indonesia Instagram posts as the efforts for brand building during Indonesia's Ramadhan month and the Eid Al-Fitr celebration.

\section{Review of Literature}

Talking about language and brands is undoubted quite an exciting discussion to discuss, and there have been several literature reviews that have been written previously regarding languages and brands. The author himself has sorted out several literature writings that are considered to have almost the same slice and become a reference for the writing of this research. One of them was a proprietary article (Citra \& Syahlani, 2008) when they looked at the effect of domestic brands and country of origin information on consumer perceptions and attitudes. Citra \& Syahlani (2008) found that people trust and think that products with brands in English are more than products with brands in Indonesian. In addition, the image of the product also increases, even though the product comes not from Indonesia, and vice versa.

Of course, if we talk about brands, we need to know the true meaning of these brands. Indonesian Legislation No. 5 mentions that a brand is an image, sign, logo, or words made of two or three dimensions to differentiate a product from other products (Undang-Undang Republik Indonesia No 20, 2016). Nufrahaini et al. (2014) also argued 
that a brand could also be interpreted as the design of a symbol to differentiate the product in the market world.

So, it can be interpreted that a brand is a face or identity of a product in the market itself. Like humans with different facial characteristics, it is the same as a brand that must have unique features that differentiate this brand from other brands. If the brand is the identity of a product, of course, everyone's view of each particular identity is different. It is the same with brands where each person's view of the brand is different and not the same. Likewise with the brand image where the brand image itself reflects the customer's reflection and views of a particular brand (Kotler et al., 2016). According to Shimp (as cited in Bastian, 2014), there are three main components for measuring brand image:

1. Attributes

Attributes are part of the product being marketed and are the characteristics of a product. Examples (price, color, text, product packaging)

2. Benefits

Benefits are the uses of a product that users or consumers directly feel.

3. Overall Evaluation

Overall evaluation It is the consumer's overall experience of a product.

A positive brand image is closely related to consumer loyalty, the willingness of consumers to look for a brand, and finally, the trust of consumers in the brand (Fensi \& Christian, 2018). This opinion is in line with research conducted by (Harahap et al., 2021) that consumers are the company's assets that must be maintained to remain loyal to the products produced. According to Keller (Yusuf, 2021), brand image is a parameter of the brand's success, product, or company. The elements that make up a brand image are the business scenario, the brand association, the consumer's assessment of the brand, and the target market (Yusuf, 2021). These elements are the factors forming the brand image in the minds of customers. Therefore, we can say brand image reflects consumer feelings and consumer responses to a brand. Language acquisition is a crucial element in linguistics. Language acquisition itself is a term for the learning process of a foreign language into an everyday language (Maharani \& Astuti, 2018).

When developing promotional products and advertisement campaigns, businesses must still exercise caution in their language. Though some of today's customers are undoubtedly diverse, they all possess a keen sense of marketing and sales promotions. If the promotional campaign is inadequate, includes unnecessary phrases, or fails to connect with the target demographic, the brand's reputation would almost certainly suffer.

\section{Research Methods}

This study used a descriptive qualitative approach with Oswald's semiotic analysis method of marketing to achieve the objectives of this study. The unit of analysis for this research was taken from every Instagram upload of Starbucks Indonesia and Coffee Bean Indonesia with the theme of the month of Ramadan and Eid or Eid. This research included interpretive research and the shade of the semiotic tradition. Because the process of interpreting the use of language is studied using the semiotic method.

The data collection technique in this research is an observation technique. Every data collected in this study results from direct observation from the researcher of each object being studied (Marta et al., 2019). In this study, researchers have two data types in this study: primary and secondary data. Primary data results from direct research observations from Starbucks Indonesia, Instagram, and Coffee Bean Indonesia. In contrast, secondary data is the findings of supporting theories and analyzes of language acquisition and brand image. 


\section{Results and Discussion}

Semiotics is the science of seeing and interpreting signs and seeing how these signs symbolize something Fiske is inside (Marta \& Septyana, 2015). Therefore, in this study, the researchers tried to see English as a symbol of the brand image of the Starbucks coffee brand and Coffee Bean. Semiotics has many figures who are very influential in the study of semiotics itself, such as Ferdinand de Saussure, Charles Sander Peirce, Roland Barthes, and many more.

According to Saussure (as cited in Marta \& Septyana, 2015), semiology is an action carried out by every living being, which becomes meaning and can be interpreted by other living things. Nevertheless, in fact, the term marketing semiotics became popular only when an anthropologist named Laura Oswald combined semiotics with marketing. Marketing semiotics systematically aims to make consumers remember and feel a symbolic relationship with a brand (Oswald, 2015).

According to Gandakusumah \& Marta (2021), marketing semiotics is an attempt by companies to group data from the company's target market. Given that consumers actually not only buy a product, but behind it, consumers also buy the meaning or message of a product (Astuti, 2018).

Oswald (Marta \& Septyana, 2015) argues that marketing semiotics has three essential basic elements: the main components in building a brand image and even the image of a company. The three components are sign, strategy, and brand image. These three components are often referred to as consumer brandscape by Laura Oswald, where consumer brandscape is the bridge between culture, brand, and consumers. Therefore, consumer brandscape is one of the best ways to measure a company's brand image or the brand itself.

Language choice of Starbucks Indonesia and Coffee Bean Indonesia analysis is divided into four main structures divided into four quadrants: mature group and young group are the $y$-axis, which can be seen from the language choice used by Starbucks and Coffee Bean. While the x-axis displays Individual versus Social dichotomy, which can be seen from the choice of words and promotions carried out in the month of Ramadan and Eid al-Fitr from Starbucks Indonesia and Coffee Bean Indonesia.

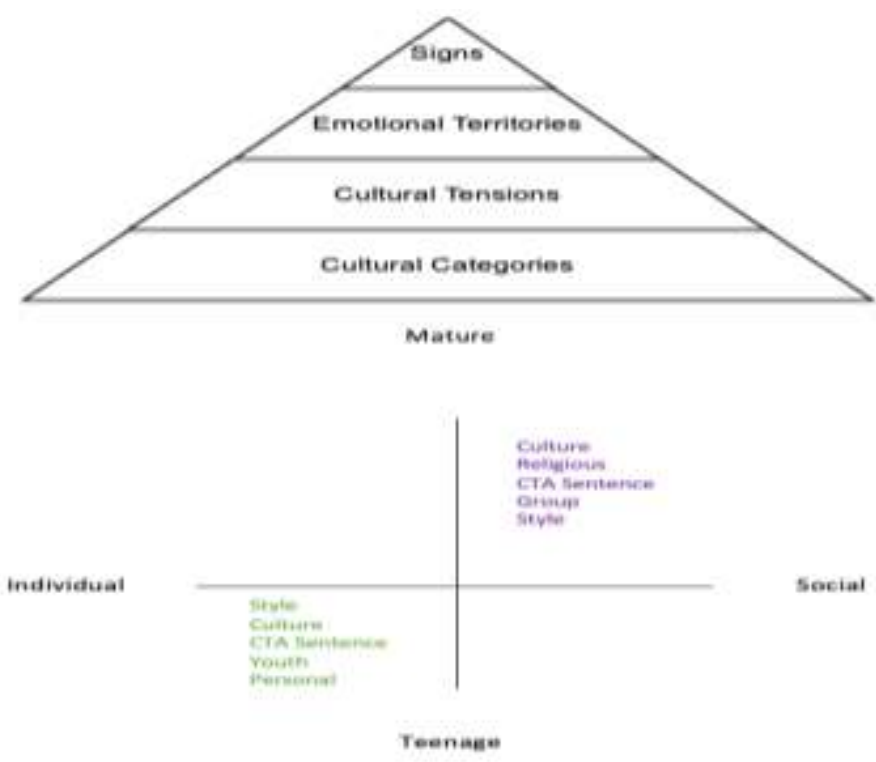

Figure 1. Consumer Brandscape

Source; Processed by the Researchers 
After the researcher examined the units of analysis of this study: they are the Instagram accounts of Starbucks Indonesia and Coffee Bean Indonesia. The researchers examined the content of Starbucks Indonesia and Coffee Bean Indonesia using the binary analysis method to see how word choices were made on the brand images. Researchers found that both Starbucks and Coffee Bean both used Instagram as a form of their social media marketing, primarily to publish ongoing promotions at their respective outlets.

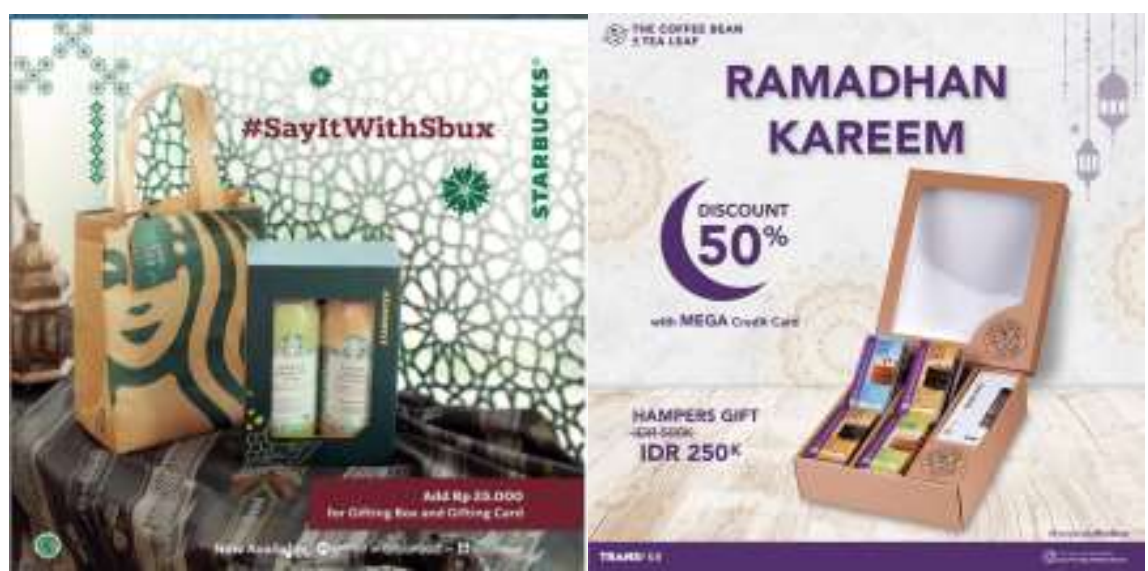

Figure 2. Ramadhan Hampers from Starbucks dan Coffee Bean Source; Instagram Starbucks Indonesia dan Coffee Bean Indonesia

Referring to the Instagram post above, we can see that both Starbucks Indonesia and Coffee Bean Indonesia use English as a CTA (Call To Action), which is an invitation to encourage potential consumers to influence, and the final goal is to buy the product (Jung et al., 2020). Such encouragement is evident from the writing font size in English, which is more significant than other writing.

The function of the English writing above is to invite consumers to buy hampers offered by Starbucks and Coffee Bean. We can see that Starbucks uses a simple sentence, "Say It With Sbux,"' which means that Starbucks Indonesia invites people to celebrate Eid Al-Fitr with Starbucks crafted hampers or can be interpreted as celebrating Eid by giving Starbucks hampers.

Meanwhile, Coffee Bean Indonesia uses the familiar word to the target demographic 'Ramadhan' and a loan term from the Arabic word (مىرك - pronounced /kərim/ meaning 'generous'), thus a phrase "Ramadhan Kareem", invites the target market to act generously during Ramadhan month. One of their hamper choices is the company's generosity to the customers, and, therefore, the customers are invited to be generous by buying the hampers. It can be concluded from the two language comparisons shown on Figure 2 that Starbucks uses sentences that are simple and easier to understand by many young people depicted from the simple and most frequent word 'say' and 'it.' The pronoun 'it' does not need a complex exemplification of what the referred noun. Such word choice is considered to be short and straightforward. On the contrary, Coffee Bean Indonesia uses more mature language and sentences since the 'kareem' word constitutes a solemn, deep sincerity, religious, and culturally original to the target demographic. 


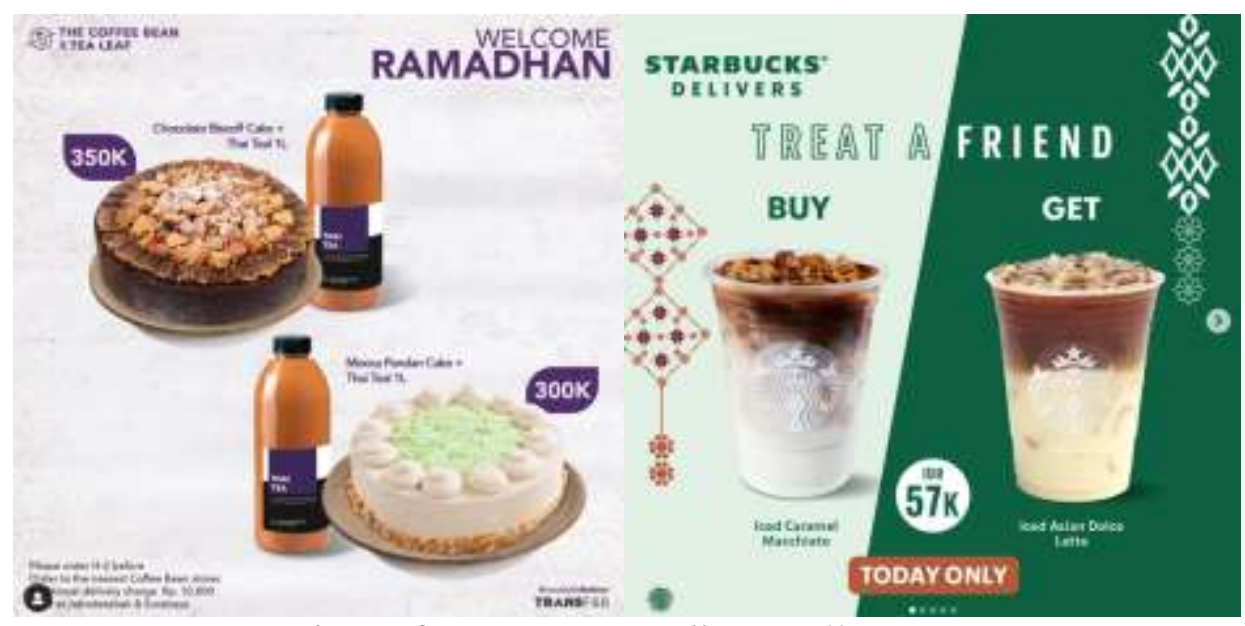

Figure 3. Promo Ramadhan Coffee Bean

Source; Instagram Coffee Bean dan Starbucks Indonesia

Looking at the campaigns from these two retailers on Figure 3, Starbucks continues to show consistency in word choices in the sentence that is simple and easy to understand by many people without particular religious background but still using elements or symbols that have the characteristic of Eid Al-Fitr. In contrast to Coffee Bean Indonesia, use the CTA "Welcome Ramadhan" and offer 1-liter beverage products and a whole cake. If we look at the promotions run by these two outlets, Coffee Bean outlets are promoting groups or families. At the same time, Starbucks Indonesia tends to be more personal or individual.

After the researchers employ Oswald's semiotic analysis method at Starbucks Indonesia and Coffee Bean Indonesia's marketing campaigns, the researchers reach the decoding stage of both Starbucks and Coffee Bean data. The researchers had classified each of the elements contained in Starbucks Instagram posts and Coffee Bean in the month of Ramadhan.

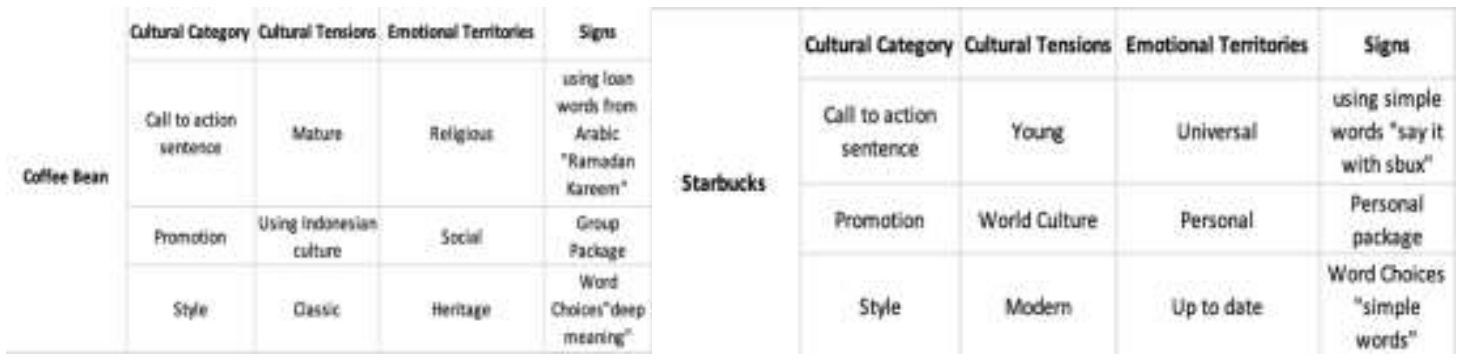

Figure 4. Decoding Binary Opposition of Coffee Bean dan Starbucks

Source; Processed by the Researchers

\section{Conclusion}

Language choice and use are one of the most eminent elements in marketing communication. Unwanted consequences are likely to happen if marketing communication is solely dependent on language skills without a thorough understanding of the cultural values governing individual cultures. Language components are not only a means of communicating in this regard; they also have an impact on interpretation and thinking. Starbucks Indonesia, in the month of Ramadhan and Eid Al-Fitr, introduces brand with a universal approach avoiding words or phrases that offend other religions. General vocabularies are used in their Ramadhan promotional campaigns. Perhaps, Starbucks 
Indonesia has a target market for young people and is more personal. The language used is more straightforward but still contains cultural meaning share. Meanwhile, Coffee Bean Indonesia itself introduced its brand with a more dynamic approach closely related to Indonesian religion and culture. The use of more profound language, taken from the uptake of the Arabic word, has meanings and meanings directly related to Ramadhan and Eid alFitr, and sentences that seem more mature. During the month of Ramadhan, Coffee Bean Indonesia introduces a brand that signifies close relationship, intimate, and also relatable to the target demographic using socio-cultural word choices and images.

The two examples from global coffee shop brands have shown the ability to adapt to the cultural background of the target demographic. They successfully acknowledge new language tendencies, regional cultural trends, and current socio-cultural values, which results in triumphant brand building of the target markets.

\section{References}

Astuti, R. (2018). Semiotika Dalam Bidang Manajemen Pemasaran. Jurnal Manajemen dan Kearifan Lokal Indonesia, 1(2), 116. https://doi.org/10.26805/jmkli.v1i2.13

Bastian, D. A. (2014). Analisa Pengaruh Citra Merek (Brand Image) dan Kepercayaan Merek (Brand Trust) Terhadap Loyalitas Merek (Brand Loyalty) ADES PT. Ades Alfindo Putra Setia. Jurnal Manajemen Pemasaran Petra, 2(1), 1-9.

BPS. (2020). Ekonomi Indonesia Triwulan II-2020. bps.go.id.

Cailey Johanna. (2021). Negara Pengguna Bahasa Inggris di Seluruh Dunia: Berapa Banyak? fluentu.com.

Citra, A. C., \& Syahlani, S. P. (2008). Efek Merek Domestik VS Asing dan Informasi Country-of-Origin terhadap Persepsi dan Sikap Konsumen. Jurnal Ekonomi dan Bisnis Indonesia, 23(2), 164-177.

Crystal, D. (2003). English as a Global Language (2nd ed.). Cambridge University Press. https://doi.org/10.1017/CBO9780511486999

Diah, S. R. (2020). Januari-Maret 2020, Penjualan Starbucks di Dunia Turun 10 Persen. kompasdata.id.

Fensi, F., \& Christian, M. (2018). Determinan Citra Merek Pada Iklan Produk Gawai "Vivo" Berdasarkan Aspek "Celebrity Endorser." Bricolage : Jurnal Magister Ilmu Komunikasi. https://doi.org/10.30813/bricolage.v4i02.1659

Gandakusumah, B., \& Marta, R. F. (2021). Visualisasi Elemen Pembentuk Consumer Brandscape Melalui Oposisi Biner Semiotika Pemasaran Xing fu tang (幸福堂) dan Xi bo ba (喜悦). Jurnal Bahasa Rupa, 4(2), 167-176.

Harahap, I., Nasution, Y. S. J., \& Chairina, C. (2021). Analysis of Muslim Customer Loyalty Shopping for Fashion in the Traditional Inpres I Market in Kisaran. Budapest International Research and Critics Institute (BIRCI-Journal): Humanities and Social Sciences, 4(1), 28-38.

Harita, F. M., Sadono, T. P., Sya, M., Fernando, J., \& Goswami, J. K. (2020). Traveloka as the Ultimate Workplace for Millenial Graduates in Information and Technology. ASPIRATION Journal, 1(2), 163-181.

Jung, J., Bapna, R., Golden, J. M., \& Sun, T. (2020). Words Matter! Toward a Prosocial Call-to-Action for Online Referral: Evidence from Two Field Experiments. Information Systems Research, 31(1), 16-36.

Kotler, P., Keller, K. L., \& Manceau, D. (2016). Marketing Management, 15e édition. New Jersy: Pearson Education. 
Maharani, T., \& Astuti, E. S. (2018). Pemerolehan Bahasa Kedua dan Pengajaran Bahasa dalam Pembelajaran BIPA. Jurnal Bahasa Lingua Scientia, 10(1), 121-142. https://doi.org/10.21274/ls.2018.10.1.121-142

Marta, R. F., Fernando, J., \& Simanjuntak, R. F. (2019). Eksplikasi Kualitas Konten Peran Keluarga pada Instagram@ KEMENPPPA. Ettisal: Journal of Communication, 4(2), 137-150.

Marta, R. F., \& Septyana, V. (2015). Semiotika Pemasaran pada Brand Value Melalui Sign Berupa Layout Berita dan Iklan Ibadah Haji (Studi Komparasi pada Harian Pos Kota dengan Rakyat Merdeka). Semiotika : Jurnal Komunikasi, 9(2), 482-508.

Nugrahaini, R. L., Adiarni, N., \& Najamuddin, M. (2014). Analisis Penguatan Merek Dalam Membentuk Ekuitas Merek pada Minuman Sari Buah Bb (Studi Kasus: Mahasiswa (end user) di Fakultas Sains dan Teknologi). Agribusiness Journal, 8(2), 189-201. https://doi.org/10.15408/aj.v8i2.5137

Oswald, L. R. (2015). The structural semiotics paradigm for marketing research: Theory, methodology, and case analysis. Semiotica, 2015(205), 115-148. https://doi.org/10.1515/sem-2015-0005

Rahayu, R. S. (2018). Studi Literatur: Peranan Bahasa Inggris Untuk Tujuan Bisnis Dan Pemasaran. 1(4), 149.

Undang-Undang Republik Indonesia No 20, (2016).

Yusuf, A. (2021). The Influence of Product Innovation and Brand Image on Customer Purchase Decision on Oppo Smartphone Products in South Tangerang City. Budapest International Research and Critics Institute-Journal (BIRCI-Journal, 2(1), 472-481. 